\title{
Rites of sacrifice among the Lugbara
}

Rites de sacrifice chez les Lugbara

John Middleton

\section{(2) OpenEdition}

\section{Journals}

Electronic version

URL: http://journals.openedition.org/span/475

DOI: $10.4000 /$ span.475

ISSN: 2268-1558

\section{Publisher}

École pratique des hautes études. Sciences humaines

\section{Printed version}

Date of publication: 1 September 1979

Number of pages: 175-192

ISSN: 0294-7080

\section{Electronic reference}

John Middleton, «Rites of sacrifice among the Lugbara », Systèmes de pensée en Afrique noire [Online], 4 | 1979, Online since 04 June 2013, connection on 19 April 2019. URL : http:// journals.openedition.org/span/475; DOI : 10.4000/span.475

This text was automatically generated on 19 April 2019.

(c) École pratique des hautes études 


\title{
Rites of sacrifice among the Lugbara
}

\author{
Rites de sacrifice chez les Lugbara
}

John Middleton

\section{Men, forces and powers}

1 In this short paper I wish to discuss some aspects of the rites of sacrifice as practised by the Lugbara of Uganda. ${ }^{1}$ It is a preliminary account: a total study would require far more space than is available here, and will be published on a later occasion. I wish here only to consider essentially the single problem of the relationship between forms of ritual offering, sickness, sin, and the continual process of restructuring ordered social relations. The Lugbara themselves, when talking about ritual offerings, offer only certain stereotyped phrases about them. Also the degree of cultural variation from one part of Lugbara to another is so great that there appears to be no fixed forms of ritual behaviour associated with sacrifice, nor many generally accepted views as to the aims of these forms of behaviour. The area of "sacrificial" behaviour is not very clearly marked off from other forms of ritual activity. Nonetheless, it is possible to define and discuss certain fields of activity that are found throughout Lugbara and which may clearly be called "sacrificial".

2 The Lugbara live in northwestern Uganda and number a little over a quarter of a million people. They are sedentary peasant farmers growing grains and keeping some livestock. They lack traditional chiefs, although chiefs have existed during and since colonial rule. They have about sixty territorial groupings which I call subtribes, each based on a patrilineal subclan and each numbering about 4,000 people. There are some 200 persons to the square mile, and disputes over the allocation of land are continual. Each subclan has its rainmaker, but effective everyday political authority is vested in the elders of small three- or four-generation lineages. Compared to many African peoples, the Lugbara construct a great many shrines in and near their homesteads, at which offerings are made to the dead and to many kinds of spirits. I refer to the dead and spirits as "forces" which are believed to exercise "power" over the living. ${ }^{2}$ 
Living men and women come into contact with these forces in two ways: the latter are believed to send sickness or possession to the former, who in response make offerings to the latter. This communication is not a daily or regular activity (although it is always possible for communication to be made) but its occasions are related to the occurrence of crises in the ever-changing networks of relations between persons and groups. Whereas in many societies periodic rites are important they are not so among the Lugbara.

4 Let us look briefly at the way in which Lugbara perceive their world. They say that the world was created by Divine Spirit (Adroa 'ba o'bapiri, Adroa the Creator of Men), ${ }^{3}$ who set male and female twins on the earth. After several generations of incestuous twins the two Heroes were born who begat the founders of the sixty clans. Lugbara say that society is based on the proper recognition of patrilineal descent and the relations of authority sanctioned by it. The dead have authority over the living, the old over the young, and men over women. Each subclan is under the mystical protection of its rainmaker (Middleton 1978). A myth tells that once men could climb a rope or tower to communicate directly with Divine Spirit in the sky. But the tower was broken and since then men have lived on earth able to communicate with Divine Spirit only through various intermediaries. This breaking of communication means that people no longer have knowledge of the former perfect society but live in one filled by imperfections, contradictions, and continual disputes within and between the myriad small local groups. People say of those who quarrel: "They do not understand the words of Divine Spirit and the ancestors", and "When people become sick by being sent sickness by the dead or by spirits, this is to show them what is proper behaviour". Sickness and possession are not regarded as punishments but rather as lessons to show people something of the ultimate Divine truth. These acts help people to redefine the social order, to maintain proper roles and relationships, and to remove uncertainties and ambiguities in social and moral categories. This redefinition and reordering are achieved through rites of offering which show what are the proper or "true" relations of authority and then reorder them by forms of dramatic statement and thereby validate them publicly. Since most relations of authority are those of the patrilineage, the relations between living and dead are continually restated by the recognition and affirmation of "true" genealogies which reflect the actual distribution of authority (Middleton 1960).

5 I should say more about the levels of experience that I have mentioned. Here on earth live ordinary people, ignorant of cosmic and ultimate moral truth, localized in time and space, and subject to all kind of external constraints over which they have no control. Outside, over and beyond them, dwells Divine Spirit, the source of moral truth, not localized in time or space, and omnipotent as source of both good and evil, able to kill people and to send them epidemics. There is a third and intermediate category, whose occupants have elements of both human and divine and are figures of ambiguity and anomaly. They include, first the dead. The dead are members of their lineages; they dwell under the homesteads of their descendants who respect and feed them. All are known as $a^{\prime} b i$, "ancestors", and those who have left male children are also known as ori, which I translate as "ghosts". The second kind of intermediary personages or forces are the spirits, adro. They are refractions of Divine Spirit, Adroa. Unlike Divine Spirit, they may dwell near men, although not visibly. The third personages in this intermediary category are rainmakers, prophets, diviners, and elders when in a state of purity and so able to make sacrifices. Lugbara also use two crucial notions in this regard. They are those of "in the home", akua and "outside", amve. Living persons are "in the home", Divine Spirit is 
"outside", and the various intermediaries are, situation-ally, both "in the home" and "outside".

6 Communication with Divine Spirit by ordinary people is not possible: the distance is too great. All such communications pass through intermediary personages. The dead and spirits communicate with the living by sending them sickness, possession, or dreams. Rainmakers can communicate with Divine Spirit when in their rain groves, places of divine power outside the realm of ordinary men, or when in the remote bushland. Prophets communicate with Divine Spirit by being in a state of trance. Elders communicate with the dead by sacrifice and by "thinking" of them while sitting near their shrines. Diviners communicate with the dead and with spirits when in a state of trance.

\section{Rites of offering}

7 I turn now to a consideration of some aspects of rites of sacrifice. In all Lugbara rites the details change from one occasion to another and from one lineage group to another. These variations represent efforts by the participants to emphasize certain significant aspect of a particular rite. For example, if the sacrificer ${ }^{4}$ considers that Divine Spirit is in any central way involved in a case then a sheep may be offered in place of an ox or goat, since sheep are considered as being particularly associated with Divine Spirit. The variations also represent discrepancies in elders' opinions and memories of what should be done in communication with certain categories of dead and spirits, and their views as to how many and which may be involved at the same time in a particular case.

The shrines found in a typical Lugbara homestead are of several kinds:

i) the shrines for the ghosts of patrilineal ancestors. These are the most important shrines (not the most powerful) in the sense that most sacrifices are made at them. They are placed in the compounds and also outside in the bush. The latter are for the more distant ghosts who are regarded as so powerful as to be dangerous if given shrines in the compounds;

ii) the shrines for the collectivities of patrilineal ancestors. There are several kinds but all are less powerful than the ghosts;

iii) the shrines for matrilineal ancestors and ghosts, placed both within and outside the compounds. The more powerful are greatly feared and are associated with fertility; iv) the nonancestral fertility shrines, placed outside the homesteads;

v) the shrines set for the many kinds of spirits. They are mainly for spirits originally associated with prophetic cults which have now ceased; the spirits have become individual and autonomous. The shrines are set outside the compounds, as associated with the forces of the wilderness, beyond control of human being.

9 Living people make offerings at these shrines as a response to various forms of communication from one or other of the mystical forces associated with them. The typical form of communication is sickness. There is a fairly generally recognized mystical aetiology of sickness, details of which need not to be given here, and consultation is made of oracles and diviners in order to confirm the suspected aetiology and to discover the details of the offerings the details of the offerings that should be made. There is not the space here to give accounts of all these rites, nor even of a majority of them. Some of them involve offerings presented at the various shrines, and others do not, being made to 
forces for which shrines need not to be placed. Therefore I select only four rites, which illustrate the main points under consideration in this essay. These are the rites of "cleansing the body", of sacrifice to the patrilineal ghosts, of an offering made to Divine Spirit, and of an offering made to a spirit. I have published accounts of most of these elsewhere and here present only a brief outline of the more significant elements.

There are many situations for the performance of the rite of "cleansing the body", rua edezu $u^{5}$ typical case is that of the sickness of a man who has quarreled seriously with a close kinsman who then dies before the quarrel is made up; he has died with a "bad heart". If the sick man should inherit the deceased's widow then the sickness may later strike their child. Guilt or responsibility are irrelevant: such sickness will befall the living person even if the original responsibility for the quarrel were that of the deceased. Oracles and then diviners are consulted (since one begins with oracular consultation but only a diviner can "know the words" of Divine Spirit), and it is then discovered that the sickness has been sent by Divine Spirit. The rite is performed by the lineage elder. A sheep is identified with the sick person, by being led around his homestead, consecrated by a ritual address, and then slaughtered. The meat is consumed by living members of the lineage; it is not offered to the dead nor to Divine Spirit. A somewhat similar rite is performed, mainly in cases of illegitimate pregnancy or persistent intersegmental quarreling, when the interests of the whole group are concerned, called "cleansing the (lineage) territory", angu edezu. There are many variants of these two rites and the situations in which they are performed are many also, but all are rites of purification of sickness brought by Divine Spirit. The all include "encircling" the homestead or the head of the sick person, as means of identification of the victim with him; a blessing by elders using spittle, breath, and sacred leaves; later consultation of hyena droppings as a sign of the rite's success or failure; and consumption of the meat by the living congregation only.

11 A sacrifice to the ghosts (ori owizu) also begins with sickness, shown by oracles to have been sent by the dead. An animal is identified with the sick person (by "encircling") and consecrated for this particular offering by the elder. Later, when the sacrifier has recovered from the sickness, the rite is performed in his homestead. It includes the slaughter of an animal - a goat, ox or fowl, in most cases, a sheep being associated with Divine Spirit rather than with the dead. The meat is divided into three portions: one for the dead, which is placed within their shrines; one to be cooked and eaten by the members of the congregation; and one to be taken home uncooked by them and later redistributed by them among more distant patrilineal kin. The sacrifier is blessed with spittle and breath, using sacred leaves, and the meat consumed by the members of the congregation sitting by generation and not by lineage segment, a sign of unity.

The third case is that of the offering of a sheep to Divine Spirit by a rainmaker in order to end drought or to remove epidemics such as meningitis. The dead are not involved; there is no slaughter or eating of the animal; there is no direct purification. It is said that once this offering was of a human being, who was disemboweled on a hill, and that the sheep is a surrogate. The rite is known as a a'izu, "to pray" or "to beseech". A rainmaker decorates a white ram with the beads of a man who has died of the meningitis, and after "encircling" the entire subtribal territory with it drives it across a river into the mountains where it is said to become a leopard and then rain (which stops both drought and meningitis).

13 There are many kinds of offerings to spirits. Spirits are "in the air" and so free of locality; they communicate by either possessing a person or sending a form of sickness that 
involves trembling or trance; they can be contacted only by diviners who go into trance while sitting in the darkness of their huts; a diviner acts as the sacrificer, calling the spirit and offering it grains and milk, some of which may be consumed by the sacrifier. The offering is made outside the compounds, often far away in the bushland and near a river, the places of spiritual power. There is no congregation. The offering is made to recognize the mystical link that has been made by the spirit between itself and the sacrifier.

\section{The notions of sin and pollution}

If we are to comprehend the meanings and the structural significance of these and other rites, we must consider to what extent is the sacrificial process concerned with sin and pollution. One immediate problem is that Lugbara notions of pollution (from which one might expect to adduce the commission of sin) are not greatly significant for them, at least in the sense that they appear slight and to be ill-defined. It follows that Lugbara notions of "sin" are also somewhat ill-defined and uncertain.

Some of the actions that may be followed by sickness associated with what may be thought of as sin and pollution are known as ezata. ${ }^{6}$ Ezata means literally "act that destroys", and is used to refer to actions that disrupt and destroy orderly and accepted relations of authority within the lineage and the family cluster formed around it. The word is not used for other actions. The definition of a particular act as ezata depends, of course, on whether the oracles state that it has offended the dead rather than Divine Spirit or other forces, rather than on any intrinsic quality of the act itself. Other terms that are used in what we might call "sinful" situations are o'yo, nyoka, o'du and onzi. O'yo is a promise or oath made by an individual (either publicly or in his own mind) that he will not do a particular action. If he fails to carry out this "promise" then he may fall sick as a consequence of the anger of Divine Spirit. Nyoka is used for a condition in which a lineage is dying out and likely to become extinct (it can therefore only be defined after the actual extinction of the group). It is regarded as a punishment sent by Divine Spirit after repeated evil actions by its members and there is no means by which it may be adverted. o'du is an omen, of which there are many, sent to an evildoer by Divine Spirit, usually in the form of lightning or of unusual occurrences at nighttime. Omens are regarded as forewarnings of later sickness or of nyoka. I return below to a consideration of the word onzi, usually translated as "evil" or "bad" but having a more specific significance than those words might imply.

Certain acts are believed to lead to sickness and even death; certain of them may be considered as sins. They include incest, homicide, illegitimate pregnancy, persistent quarreling, persistent fighting by an aggressive lineage group, and so on. They are followed by various forms of sickness or by omens that are later followed by sickness. They also, in most cases, require cleansing or purification by the rites of rua edezu or angu edezu, followed by the consultation of mystical signs (usually in the form of hyena droppings) to check whether or not the anger of Divine Spirit has been lifted. It is clear that, as I have mentioned, these rites also follow acts in which "sin", if defined as a responsible or guilty act, is not involved. The rites are directed to Divine Spirit and not the ancestors, even where acts against the norms of lineage and kinship are involved. They are rites of purification and although there are no very clearly formulated analyses made of them by the Lugbara themselves, I think that it is clear that they are considered rites by which Divine Spirit is asked to remove the state of danger that it has sent as 
punishment or warning. They are akin to the rite by which a rainmaker sends a ram into the wilderness to "pray" to Divine Spirit to remove drought or pestilence and thereby purify the subtribe and its territory. An important point is that they do not involve the sacrifice of animals in the sense of a blood sacrifice being offered: Divine Spirit does not "eat" meat or blood.

There are, however, rites at which meat is given to and "eaten" by the dead, and others at which nonblood offerings are made to spirits. These are known generically as owizu, a term which Lugbara say cannot be used with reference to the proper rites of purification. Owizu is linked with the notion of something being "left over", awi, the dead "eating" the meat "left over". In rites known as owizu, meat and other offerings are consumed by the living and the dead and spirits, as a means of "thanking" them for having sent sickness to a disobedient individual to "show" him that he has flouted authority and ignored behaviour proper to his status.

18 I have distinguished rites of purification from those of ancestral or spirit offerings. But in actuality they are not always distinguished clearly. Since Divine Spirit cannot be contacted directly by a living person (other than a rainmaker or a prophet), the latter must request the dead to do so (one cannot so request a spirit, since they do not understand human words). Divine Spirit "stands behind" the ancestors. Therefore Divine Spirit is involved, to a greater or less extent, in all offerings to the dead; and they are involved, again to a greater or less extent, in efforts by the living to request Divine Spirit to purify those persons guilty of sins. Even though the distinction is thus not always very clear-cut, I think none the less that it must be made.

I turn now to the notion of pollution. I have used the word because it is in common usage in religious studies, but it requires discussion in the Lugbara context. It is, in this case at least, somewhat misleading in that there is the connotation that pollution is something that is passable from one person to another by mystical contagion. This notion is present in Lugbara thought, as for example in the case of a widow being contagious to other women until purified, but it does not appear to be a very central or clear one to them. It is more useful to return to the classic discussion by Hubert and Mauss and to enquire whether, in the case of the Lugbara, we should consider sin, pollution and sacrifice in the context of acts that lead to changes in the moral condition of the sacrifier or his group.

\section{Moral condition and moral status}

First we need to distinguish the notions of "moral condition" and "moral status", even though they are intimately linked. In Lugbara thought, at least, an essential point with regard to changes in moral condition and moral status is that of the identity of the force that is considered able to change them in the case of any particular individual or group. In a sense, any individual or group can change their moral condition by their own wishes and activities, since they can exercise at least a degree of free will. But in another sense only Divine Spirit (and perhaps refractions of Divine Spirit) can do so: Spirit may either recognize the individual's wishes in this regard or may change his condition irrespective of those wishes.

21 We are talking of the moral condition of persons, that is, of individuals who hold particular statuses in particular networks of relations of authority. "Moral condition" as conceived by the Lugbara is defined by reference to the degree to which the three inner 
or moral elements of an individual are in unison, agreement, or balance. In Lugbara belief a man comprises certain elements. Besides his body and his breath (the latter the sign of life in the former), he has a soul (orindi), a spirit (adro), and an element known as tali. Only men have souls and older men have stronger souls than younger ones. It is the seat of responsibility and authority as a member of a lineage, and on death it leaves the body to join Divine Spirit in the sky before being brought back and redomesticated as a ghost by a diviner who erects a shrine for it where he will receive offerings of food from its living descendants. The adro is placed in the body by Divine Spirit and stands for the individuality of its possessor: one with an overly strong spirit acts ambitiously and antisocially, as do witches. The tali is the seat of the ability of an individual to influence others apart from the exercise of lineage authority (Middleton 1973). The balance within the living individual is therefore that between his sense of lineage and familial responsibility, his sense of individual ambition, and his sense of what is proper in relations of mutual influence with his neighbors. When these are in balance then his behaviour and reputation are "good", onyiru. When they are not so, then his behaviour and reputation become "evil", onzi. His moral condition has become altered. Divine Spirit can know to what extent this balance has occurred, since it is thought that Spirit is at least ultimately responsible, and can show it to the individual's kin through the words of a diviner. To some extent of course these living kin suspect the imbalance by observing his behaviour, but they cannot be certain of it without divination.

The dead have relatively little to do with an individual's moral condition. They are fare more concerned with his moral status, the position he holds in the system of ordered relations of authority within lineage, family and neighborhood. The obligations and rights of each lineage status are clearly recognized and defined, at least in principle. The relationships between status and moral condition are of course not always apparent either to a particular individual or to those around him, due to his ignorance or duplicity or their stupidity. And so lack of congruence between them is shown to people by the sending of sickness by Divine Spirit.

We might state that the rites of rua edezu and angu edezu are performed because the sinner is polluting to others, and this pollution must be removed by Divine Spirit who has originally sent it. But what exactly is this pollution and what has it polluted? I think that it is more accurate, and closer to the notions of the people themselves, to say that the "pollution" (for which there is no single term in Lugbara) refers both to the sacrifier's being onzi as defined above, and to the notion of ole, "indignation" or "moral anger" on the part of both the living and the dead. Divine Spirit has, in a mysterious way and often for mysterious reasons, disturbed the balance of the elements that compose an individual, who thereby becomes sick as a sign that the imbalance has occurred. This shows both his living and his dead kin that ordered relations of authority have been flouted, threatened, or damaged. Sacrifice is mead to the dead, since the distance between men and Divine Spirit is too great to be bridged directly. The dead act as mediators: Divine Spirit "stands behind" them.

By sickness the living individual is translated into the "outside", amwe, the realm of Divine Spirit, danger and power. By becoming "evil", onzi, he is removed from the realm of the "good", and can only be returned to the moral condition of "goodness" by being taken from "the home" to the "outside" and then brought back again. He is first sacralised, made dangerous and polluting and also, we may surmise, with his moral condition and his motives beyond the immediate understanding of his kin and neighbors. 
By the rite of rua edezu he is desacralised, brought back to the "home". As I have mentioned above, the dead are liminal, floating between the "home" and; the "outside". By the removal of pollution and "indignation" on their pari they are brought to the side of the "home", beneath the compounds. This is one significance of the rite of rua edezu. By the rite of owizu they are expected to demonstrate this and to recognize the restored balance of the former sinner's moral elements and also to recognize and to sanction the restored network of orderly lineage relations.

If we accept the distinction between a change in the moral condition of an individual and his moral status which is restored by the rite of owizu, then we must accept that both are parts of the sacrificial process. In brief, the former is a consequence of the believed action by Divine Spirit and the latter is that of believed action by the dead. There remains the problem of offerings to spirits, in which the dead are not involved at all. The significant point with regard to the action of spirits is that the individual singled out by a spirit makes an offering to the particular spirit, by which he shows that he accepts that he is now in a mystical relationship with that spirit; and that this offering is not followed by any rite involving the dead. His moral condition has been changed, but not his moral status, which remains as it was and is not, as it were, threatened or disturbed by the former. We might say that such an individual has been singled out and set apart from his lineage kin by an imbalance between his three moral elements, and that this slight imbalance "in favor of" his spirit remains to demonstrate this fact; but his lineage status is not accepted as having been changed. It is significant here that those so singled out are in most cases the younger brothers of senior men, who cannot succeed to high lineage status: their moral balance can remain slightly "tilted", which shows his difference from his follows, but that is all.

\section{Identification, consecration, and oblation}

I turn to a brief consideration of the means used to make communication with whatever mystical forces are believed and shown by divinatory means to have communicated with the living. We may accept that the crucial means involve acts of consecration and identification, by which the moral condition and the moral status of the sacrifier are affected.

In the rites described above there is a clear action of identification, by the "encirclement" of the sacrifier's head (by a fowl) or of his homestead (by an animal), or in the case of the rainmaker's rite of a'izu of the entire subtribal territory. In all of them also there is the consecration of an offering, by means either of words or the laying on of hands. I would suggest that the meaning of these acts of identification and consecration is twofold: to make a mystical link between sacrifier and victim and also to make a link of responsibility and obligation between sacrifier and the apposite intermediary (elder, diviner, ancestor). There is, as it were, a displacement of the sacrifier, a loss of independent moral status that is congruent with a change in his moral condition. He is not really "sacralised" but he is placed in an intimate association with a ritual personage who is so. By a change in his moral condition he is already in a liminal condition, "evil" and "outside"; the identification and consecration change his moral status similarly, in that he becomes a dependent of the ritual functionary. The subsequent rite returns both condition and status to normal. 

being itself made sacred, and by the presentation of a sacrificial victim or oblation. The central part of the rite is placed into sacred time and space. There are two questions: how is the change in the arena made, and how does it affect the moral condition of the sacrifier? The change in the arena is made by acts that "frame" the central part of the rite (Middleton 1977). The effect of this, is that the sacrifier goes through a classic rite de passage. The degree of change undergone varies from one sacrificial rite to another, and this is reflected in the importance and complexity of the acts of framing. The framing removes the progress of sacrificial events from ordinary time and space into an arena without time or localization. In it are represented the essential aspects of the presocial and "true" society of Lugbara myth, where the three categories of Divine Spirit, intermediaries and the living are no longer distinguished. As we can see from Lugbara myth, "space" and "time" are not rigidly distinguished. So that the framing can be made in either terms: either by entering the wilderness or by marking off in time. The marking off in time need therefore be done only in rites held inside the homestead and then it temporarily abolishes the distinction between living and dead, since that distinction is one of time. But outside the homesteads in the realm of spirit, framing cannot be in terms of time, since spirit is timeless. So that here the sacrificer and sacrifier merely enter the bushland, the area without localization. In the case of sacrifice at the external ghost shrines (which I have not described in this paper) there is framing in both time and space. In short, the sacrificer, the sacrifier, the lineage members, and the compound itself go through a period of sacredness. During this period the sacrifier loses the imbalance of his moral condition by entering a level of greater sacredness. On his return he is "cooled" by the use of breath and spittle. He has been "hot" and in a condition of power and danger and must now be cooled to regain his proper and normal moral condition. When I have asked Lugbara how this actually occurs, I have been told that ordinary people do not know although rainmakers might do so. When I have asked rainmakers, they say also that they do not know but that, when the ancestors are fed, they in some way "talk" with the sacrifier. This contact is dangerous but effective, and no one can say more about it.

What is the significance of the oblation? It is, like most offerings whether ritual or secular, a means of communication, a means of establishing or affirming a link of some kind that has special relevance to the sacrifier's moral condition. There is not the space here to discuss the meaning of ritual oblations at any length, but the position may be summarized. At ancestral sacrifices the dead are given raw meat, raw blood, chyme and chyle, and either unfermented beer or its dregs (both are undrinkable). The living consume small portions of cooked meat, mingled and cooked blood, chyme an chyle, and fermented beer. At spirit offerings, the spirits are given uncooked grains and milk; the living consume small poritions of cooked grains and milk. The pattern is clear: the living eat cooked food, the lineage dead "eat" raw, half-digested and half-brewed foods and drink; the spirits eat raw foods that are bloodless and pure, as are the spirits themselves.

The oblation is a symbol of something to be given to and shared with the dead and the spirits. In the case of the rainmaker's sheep, it is offered to Divine Spirit but, since Spirit is too remote from men, it cannot be shared. The notion of gift is complex, since the force that receives it already owns it. Originally, as I have said, the offering to Divine Spirit was of a human being, so the notion of sharing food is absent here but that of identification is paramount. The rainmaker's offering represents the assumption of the collective sins of the community: it is not "eaten". The animal offered to the dead is different. It is eaten, as

Systèmes de pensée en Afrique noire, 4 | 1979 
the principal item of property owned by the lineage, jointly by dead and living members. Kin eat together. In the case of offerings to spirits, these are not "proper" foods. There is no identification; there is no notion of the oblation carrying with it sin; and the notion of any ownership of grain or milk is lacking.

\section{Sacrifice and the social process}

This leads to my final point in this short paper: that of the relationship between the sacrificial process and the resolution of conflicts that arise as part of the developmental cycle of lineage and domestic groups. These conflicts are those between members of lineage groups, families, and neighborhoods that appear due to differing ambitions on the part of members whose relative positions continually change as they mature in the course of their lifetimes. I have discussed this in detail elsewhere and need not repeat the argument here (Middleton 1960). On the part of individuals, the younger wish in general to gain independence from the authority of their seniors, who in general themselves see as their duty to retain that authority. The pattern of behaviour is, in brief, that the younger people attempt to gain this independence by changing their moral condition in the hope that this will be transformed into a change in their moral status that is recognized by the dead, spirits, or Divine Spirit. This is of course the observer's interpretation of individual Lugbara behaviour, and not their own explicit statement, but I believe it to be accurate.

33 The continual realignment of relations is complex and subtle. The very multiplicity of shrines is a sign that the Lugbara place the mystical forces external to them into many categories. This would appear to reflect the fact that their social organization is one of many minutely reckoned differences of role and influence. Their means of resolving conflict depend largely on manipulation of the many possible combinations of roles and of influence. The process of sacrifice is a means of reordering and validating the resolution of contradictions in networks of authority, and of removing uncertainties and ambiguities in social roles. The whole process is subject to alternatives and choices made by the parties concerned: the sacrificer, the sacrifier, and the force to which oblation is made (as shown through the verdicts of oracles and diviners). These rites are part of the continual unrolling of contradictions and conflicts between persons and groups whose relative relationships are never precisely identical, or even very clearly defined, and who never regard any situation in the same way until after the sacrifice is made and the resolution of the conflict validated.

34 Any person, man, woman or child, can come into contact with the dead and with spirits; and there are means to establish the exact links of mystical communication in any given situation, by consultation of oracles and diviners. But there is also the definition of the mystical communication in the first place. A man may fall sick, have dreams, perceive omens. He may regard these occurrences as signs of communication from a mystical force. Or he may regard them as mere chance and of no significance. If they are repeated, then sooner or late he will conclude that they are signs of mystical contact.

The permutations of choice are many. Let me give two examples. A man who is sent sickness by the patrilineal ghosts is shown that he is in conflict with a senior kinsman. The sacrifice redefines and validates the genealogical relationship between them. But if he can show that his sickness comes from a particular spirit, then he shows that he has been singled out by a spirit to be under its care rather than under that of a senior 
kinsman. Such men are typically in a weak genealogical position, and to be singled out by a spirit both gives them prestige and also a new sense of independence outside everyday lineage obligations. Much the same occurs if he can show that the sickness comes from a matrilateral ancestor. A second example is that of a woman who is sick. She has a choice of showing that the sickness comes from the ancestors of her husband (a sign of her disobedience to him), her own ancestors (a sign of their protection of her against her husband) or a spirit who singles her out and thereby gives her a new identity or personality. A wife who is childless, for example, is in a position of uncertainty and ambiguity. She lacks the full status of a wife and is in a difficult position vis-à-vis her husband's kin. She does not know whether to stay with him and find him a second wife; or to leave him and find a new husband; or to take up a new status as a diviner. By being possessed by a spirit and coming under its protection, she can validate whatever decision she makes and can establish her independence. The alternatives are always many, and I wish to stress that these choices determine the kinds of sacrifices that are actually made; so that choice and decision are in fact determined largely by the disputes that are taking place in a particular family at a particular time. I have stressed the factors of conflict and of disparity, uncertainty, and ambiguity of roles. Disputes can be settled by fighting or by taking them to a magistrate's court. Although these are ways of bringing disputes to a head, they do not really settle them. A dispute is typically the expression of underlying contradictions in the structure - between persons, between lineages, between neighborhoods. To resolve these requires a recognition that the resolution is acceptable to all parties concerned and has received an "external" validation, by Divine Spirit, the dead, or the spirits. The mystical forces on which people are dependent, in their own thought, must be brought into the matter. This can be done only by symbolic communication with them through the sacrificial process.

\section{BIBLIOGRAPHY}

Middleton, J. (1960) Lugbara Religion: Ritual and authority among an east African people, London: International African Institute, Oxford University Press.

Middleton, J. (1973) "The concept of the person among the Lugbara of Uganda" in La notion de personne en Afrique noire, Paris: Éditions du CNRS, pp. 491-506.

Middleton, J. (1977) "Ritual and ambiguity in Lugbara society" in S.F. Moore and B. G. Myerhoff (eds.), Secular ritual, Assen, NL: Uitgeverij Van Gorcum, pp. 73-90.

Middleton, J. (1978) "The rainmaker among the Lugbara of Uganda” in Systèmes de signes. Textes réunis en hommage à Germaine Dieterlen, pp. 377-388.

\section{NOTES}

1. Field research among the Lugbara of northern Uganda was undertaken between 1949 and 1953 with the financial help of the Worshipful Company of Goldsmiths and the Colonial Social Science 
Research Council, London; initial writing of the material was made possible by the grant of a predoctoral fellowship of the Wenner-Gren Foundation for Anthropological Research, New York, and the award of the Alan Coltart Scholarship at Exeter College, Oxford. I wish to express my gratitude to these various bodies.

2. I make this distinction in English because of the ambiguous meaning of the word "power". English lacks the distinction between the French pouvoir and puissance.

3. In certain earlier publications I translated Adroa as "God" but now consider the term Divine Spirit to be more accurate.

4. The sacrificer is he who actually performs the rite. I use the word "sacrifier" for the person on whose behalf the rite is performed, the French sacrifiant.

5. The verb edezu means "to cleanse", "to purify", "to repair", "to make whole"; here I select the first meaning, but all are present.

6. I translated ezata as "sin" (Middleton 1960), but am no longer certain that this is a correct translation.

\section{ABSTRACTS}

The degree of cultural variation from one part of Lugbara to another is so great that there appears to be no fixed forms of ritual behaviour associated with sacrifice, nor many generally accepted views as to the aims of these behaviours. The Lugbara construct a great many shrines in and near their homesteads, at which offerings are made to the dead and to many kinds of spirits. Herein the problem of the relationship between forms of ritual offering, sickness, sin, and the continual restructuring of ordered social relations is addressed. Since living persons (save rainmakers or prophets) cannot directly contact Divine Spirit, they must request the dead to do so. There is a clear action of identification by a rite of encirclement of the sacrifier's head or homestead or, in the case of a ceremony performed by a rainmaker, of the group's territory. In all these rites, there is the consecration of an offering by means either of words or the laying on of hands.

La variation culturelle à l'intérieur du pays lugbara est si grande qu'il ne semble y avoir ni de formes fixes de comportements rituels associés au sacrifice, ni d'avis communément partagés sur les finalités de tels comportements. Les Lugbara construisent beaucoup d'autels à l'intérieur et à proximité de leurs maisons où ils font des offrandes aux morts ou à plusieurs sortes d'esprits. Le problème adressé ici est celui du rapport entre les formes d'offrande rituelle, la maladie, le péché et le restructuration continuelle de l'ordre des liens sociaux. Comme les vivants (hormis faiseur de pluie ou prophète) ne peuvent pas entrer directement en contact avec Dieu, ils doivent se tourner vers les morts. On constate une rite d'identification qui s'accomplit par l'encerclement de la tête du sacrifiant ou de sa maison ou, dans le cas d'un rituel exécuté par un faiseur de pluie, par l'encerclement du territoire du groupe. Dans tous ces rites, il y une consécration d'une offrande par des mots ou par l'imposition des mains. 
INDEX

Mots-clés: sacrifice, transgression, offrande, notion de personne, Dieu suprême, ancêtres, faiseur de pluie, rites de passage

Population Lugbara

Geographical index: Ouganda

Keywords: sacrifice, transgression, oblation, personhood, Supreme Being, ancestors, rainmaker, rites of passage 